\title{
The Impact of the Government's Incentives on Increasing Investment in Turkey's Solar Photovoltaic Power Plants
}

\author{
F.ERKEN
}

\begin{abstract}
Exhibiting a high economic growth rate in recent years, energy demand has increased rapidly in Turkey. Despite having a great potential in terms of renewable energy sources, Turkey has not utilized this potential sufficiently to meet this demand. However, among various renewable energy sources, the solar energy stands out in terms of investments and incentives in Turkey. In this study, the progress and the outlook of the renewable energy, especially photovoltaic systems in Turkey are reviewed considering the potential, the incentives and the investments. In this context, ratio of the Photovoltaic Solar Power Plants within both overall installed power and the total generated energy over the years is investigated geopolitically. Ongoing and planned investments for Photovoltaic Solar Power Plants and the incentives provided by the government are reviewed by considering the geographical regions of the country. It is observed that the installed power capacity of active solar photovoltaic power plants increases by more than four times compared to the previous year, as of the end of 2017, owing to incentives and investments. It is expected that the solar energy power capacity among the renewable energy sources contributes significantly to the total installed power capacity over the next few years in Turkey.
\end{abstract}

Index Terms - Renewable energy sources, solar energy, solar photovoltaic power plants, incentives and investments, energy projection.

\section{INTRODUCTION}

$\mathrm{T}$ HE GLOBAL energy demand has increased substantially in the last few decades owing to the many technological developments [1]. Today, fossil fuels are the primary energy source. However, their limited availability and negative environmental impact has prompted countries to pursue alternative energy sources [2,3]. Environmental concerns and the urgent need for environmental protection are increasing rapidly as a result of supplying the global energy demand produced from the fossil-based oil, coal and gas etc. The utilization of renewable energy for environmentally friendly energy systems has alternatively increased interests $[4,5]$

FARUK ERKEN, is with Department of Electrical and Electronics Engineering of Kastamonu University, Kastamonu, Turkey, (e-mail: ferken@kastamonu.edu.tr).

iD https://orcid.org/0000-0003-2048-1203

Manuscript received September 27, 2019; accepted December 16, 2019. DOI: $10.17694 /$ bajece. 626145
Besides, the quantity of renewable energy studies has increased, and the studies themselves have intensified targeting cheap and clean energy [2]. Particularly in recent years, eco-friendly Renewable Energy Sources (RESs) (also known as alternative energy sources) can be used to regenerate energy. RESs are considered as significant energy resources in many countries all around the world. RESs researches ensure that the world's growing energy demand can be met using clean and economical ways. Finally, safety concerns have increased the importance of RESs such as solar, wind, biomass and geothermal energy, as well as technologies including fuel cells [6-12].

According to the World Bank's World Development Indicators [13], about $67.03 \%$ of the total global energy is produced from the burning of fossil-based oil, coal and gas, which produces carbon dioxide $\left(\mathrm{CO}_{2}\right)$ emissions, intensifying global warming (through the greenhouse effect), as shown in Fig. 1 [14]. In the near future, billions of people, especially in developing countries, are expected to face many problems due to climate change [15], as global warming is deemed one of the most serious threats in human history $[16,17]$.

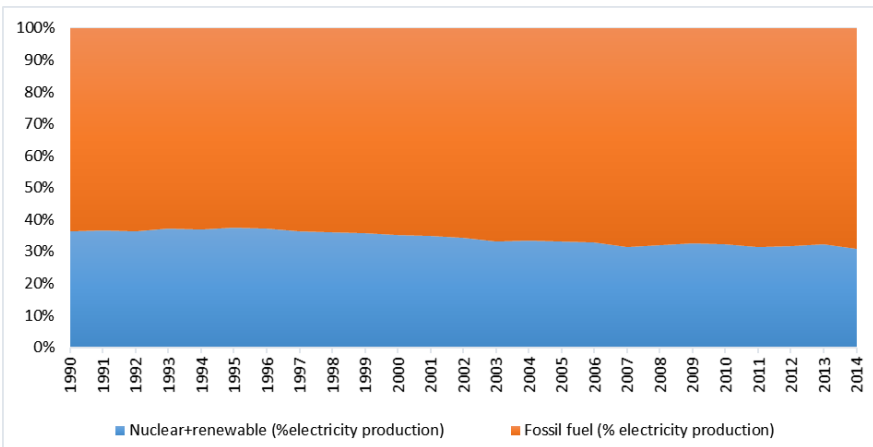

Fig.1. Global electricity production rates measured as the percentage contribution from fossil fuels (coal, oil and gas) and low-carbon sources (nuclear, hydropower, biomass, wind, solar, geothermal and marine power) [11].

Global $\mathrm{CO}_{2}$ emissions to the atmosphere have increased from 22,112 Mt in 1997, before the Kyoto protocol in December 1997, to $32,294 \mathrm{Mt}$ in 2015 , at a rate of $46 \%$ [18]. In fact, this rate is expected to increase even further, by almost $40 \%$, according to the Energy Information Administration's International Energy Outlook 2009, during the period 20062030 [19]. $\mathrm{CO}_{2}$ emissions in Turkey have also increased from 176.6 Mt in 1997 to $317.2 \mathrm{Mt}$ in 2015, at a rate of 79.6\% [18]. In Fig. 2, the $\mathrm{CO}_{2}$ emissions trend in Turkey, between 1971 
and 2015, are presented as percentage contributions from fossil fuels (coal, oil and gas). The greenhouse gas emissions continue to rise in Turkey. According to Turkish Statistical Institute, this trend has not deteriorated in 2016 and the total emission amount was $496.1 \mathrm{Mt} \mathrm{CO}_{2}$ equivalent with an increase of $5.6 \%$ compared to the previous year [20]. The $\mathrm{CO}_{2}$ emissions increased to $526.3 \mathrm{Mt}$ in 2017. The results clearly indicate that the $\mathrm{CO}_{2}$ emissions in Turkey are approximately two times greater than those in the world [18].

A major benefit of using renewable energy is the reduction of pollutant emission in the air, in the form of heating gases [21]. Thus, currently, mankind's aim is to find alternative sources of energy to enable life on the ground, without relying entirely on fossil fuels [22].

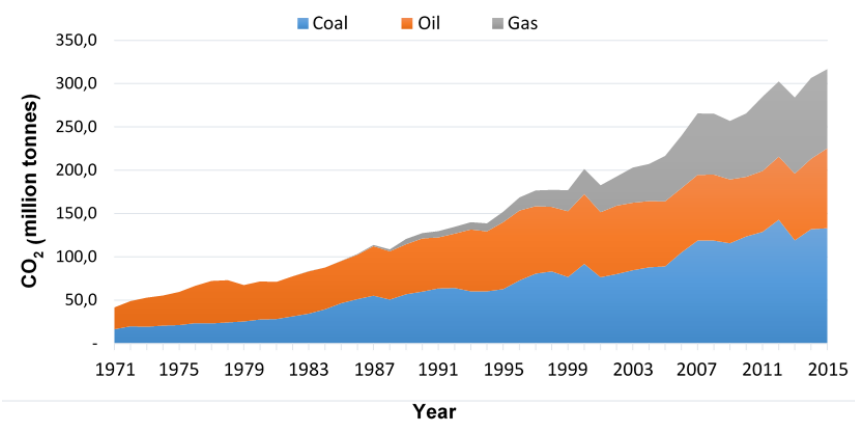

Fig.2. Trend of $\mathrm{CO}_{2}$ emission of Turkey from fuel combustion between 1971 and 2015 [16].

In today's world, awareness regarding such sources is a necessity to expand the use of all renewable energy sources because environmental problems have increased tremendously, and consequently the adverse effects of climate change have become crucial [16]. However, 26.5\% of the global electricity is produced from renewable energy sources with hydropower providing about $16.4 \%$, as $73.5 \%$ of electricity production is provided from non-renewable energy sources. Most of countries in the world target the using of the renewable energy sources and regulate their policies and several jurisdictions to increase their existing capacity [23]. As a result of these regulations, global renewable power capacity in 2017 increased to 2,195 GW while it was around 1,000 GW in 2007. Overall, renewable power generating capacity in 2017 reached its greatest annual rate with an increasing 178 GW raising total capacity by almost $9 \%$ over 2017 . The global hydropower capacity reached to $1,114 \mathrm{GW}$ with an addition of $19 \mathrm{GW}$ despite it has the smallest annual enhancement over the last five years. The leader country in hydropower installed power capacity is China, accounting for nearly $40 \%$ of new installations in 2017. Other following countries that added significant capacity are Brazil, India, Angola and Turkey. Wind power is in demand renewable energy sources with more than $52 \mathrm{GW}$ added globally in 2017 compared to 2016. The world's total capacity increased nearly $11 \%$, to $539 \mathrm{GW}$ in 2017. China is the leader country both in total installed and added capacities of wind energy. Turkey is in the top 10 for the new installations in the end of 2017. Geothermal energy is cost-effective, sustainable, and environmentally friendly energy resources. However, drilling and exploration for deep resources is very expensive. Besides, geothermal energy has been limited to areas near tectonic plate boundaries. United
States, The Philippines, Indonesia, Turkey, New Zealand, Mexico, Italy, Iceland, Kenya and Japan are the countries that have the largest amounts of geothermal power generating capacity at the end of 2017. For the new installations, Indonesia and Turkey lead with the rate of $39 \%$ and $34 \%$ during the year, respectively. Turkey's net additions were at least $243 \mathrm{MW}$, for a total of $1.1 \mathrm{GW}$ at the end of 2017 [23].

Solar energy, as one of the most important types of RESs, can be used directly in residential and commercial buildings, as well as in the lighting and heating industry. In addition, electricity can be generated through solar energy, using suntracking concentrating collectors. Alternatively, electricity can be directly obtained from solar energy using photovoltaic (PV) solar cells that convert photon energy (hv) into electrical energy [2]. Although solar PV power plants do not require mechanical maintenance since they do not have moving parts, their efficiency decreases over the years compared to other renewable power plants.

Turkey has a big potential for solar energy exploitation in the European countries because of its geographic location [27]. The rate of the solar PV in global electricity production is $1.9 \%$ in the end of 2017 . Turkey provides its electricity generation from solar energy with the rate of $6.82 \%$, which is above the world average (see Table 1) [27 28]. The Fig. 3 shows the new installations and total power capacities of hydropower, wind, geothermal and solar energies for top countries in the world.
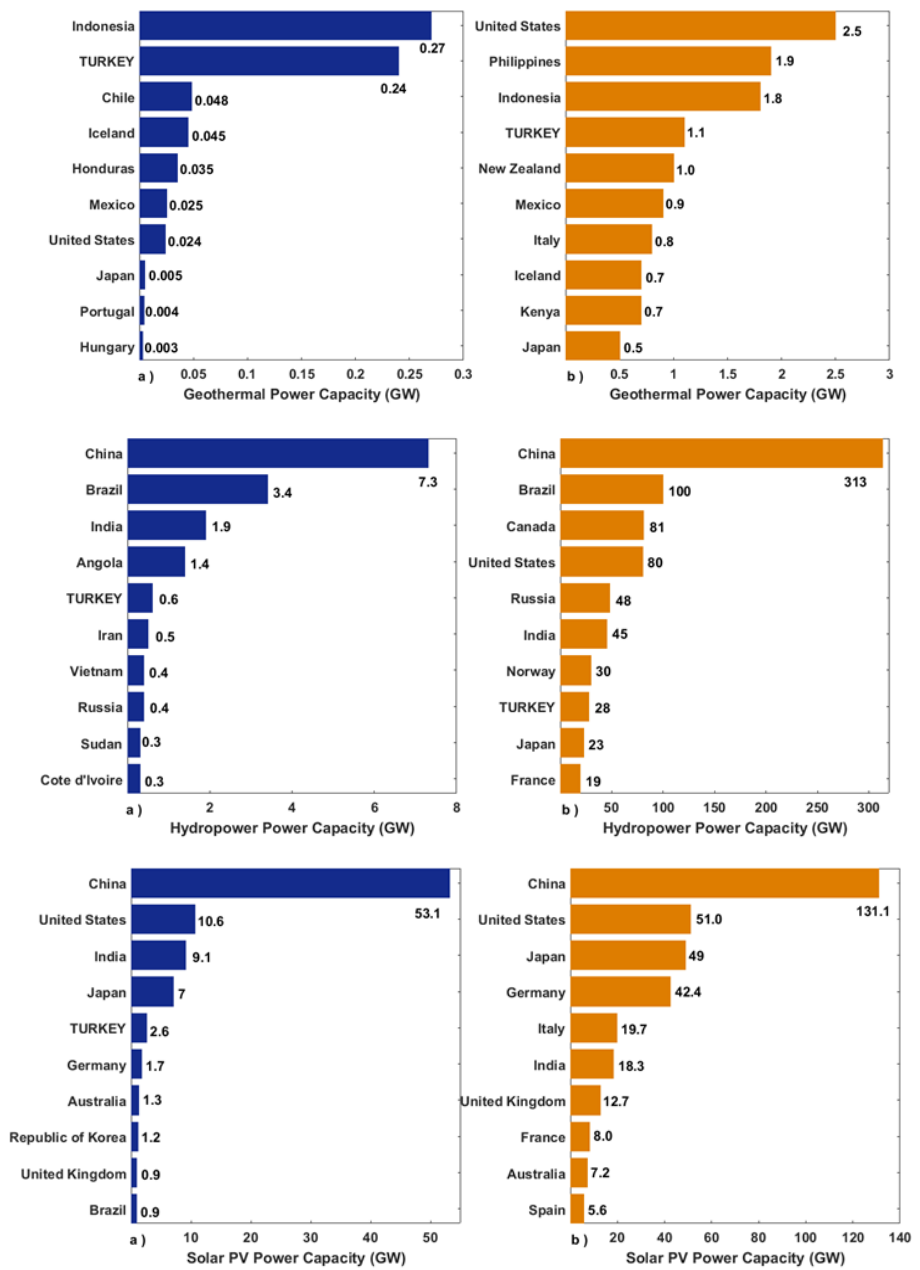


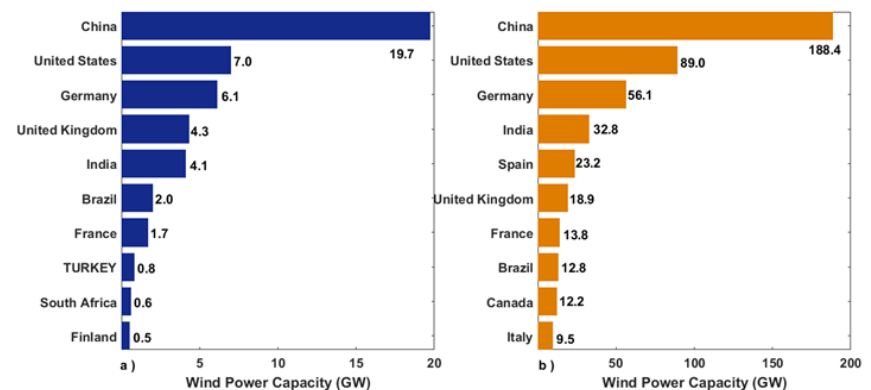

Fig. 3. The new installations (a) and total (b) power capacities of hydropower, wind, geothermal and solar energies for top countries in the world [23].

The present study evaluates the utilization of renewable energy in Turkey's energy production, especially for solar energy. The aim of the study is to focus on the production and rising of the solar energy in the electricity generation in Turkey. The present policy and legal aspects on of the feedin- tariff of photovoltaic systems in Turkey is also explained in this research. Furthermore, the effect on solar energy utilization of the incentives and project calls supported by legal arrangements are investigated in the field of solar power plants.

\section{STATUS AND PROGRESS OF TURKEY'S PRODUCTION AND CONSUMPTION OF ENERGY}

Rapid population growth and industrialization significantly increase energy demands in developing countries. Energy, as a production factor, is one of the main indicators that can be used to project the economic and social development potential of any country. There exists a linear relationship between energy consumption and social development [29]. In 2017, energy consumption in Turkey was 111,782,000 Ton Equivalent Petroleum (TEP). Specifically, within the year 2017, 44,319,000 TEP of natural gas, 13,791,000 TEP of lignite and 24,707,000 TEP of fat coal were consumed in the country. The consumption rate of natural gas was 53,720 million per $\mathrm{m}^{3}$ in 2017 , whereas its importation rate was $99 \%$ of the natural gas consumed for energy production. The imported natural gas also had an important role in the production of electrical energy as seen in Fig. 4 [30].

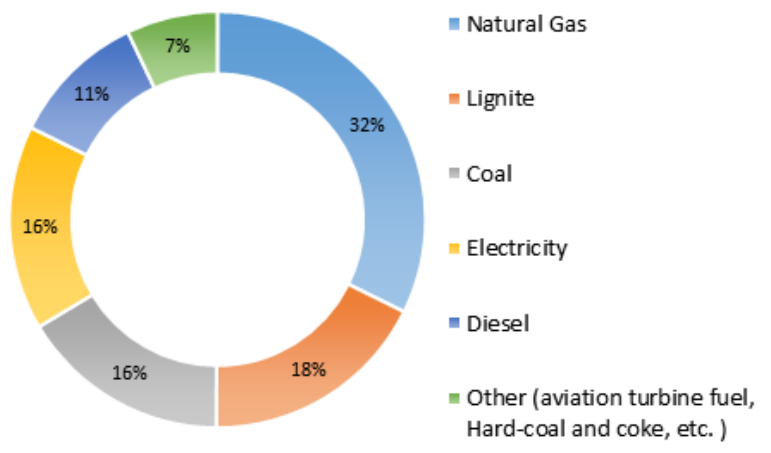

Fig.3. The distribution of the total consumption of the energy by sources in Turkey [27].
According to the 2016 report of the World Energy Council, most of the energy used globally was obtained from primary energy sources. The resources with the largest share in primary energy use were petrol $(32.94 \%)$, coal $(29.20 \%)$ and natural gas $(23.85 \%)$ [31].

Fig. 5 shows the distribution of energy resources used for the generation of electrical energy between 2006 and 2017 in Turkey. The electrical energy generated in 2006 was obtained from natural gas, lignite, coal and petrol products, at rates of $46 \%, 25 \%, 18 \%$ and $21 \%$, respectively. The use of RESs, other than hydraulic energy, was negligible in 2006. By the year 2017, these proportions reached $35 \%$ for natural gas, $19 \%$ for hydraulic, $17 \%$ for coal, $13 \%$ for lignite, $7 \%$ for solar $6 \%$ for wind and $5 \%$ for other sources.

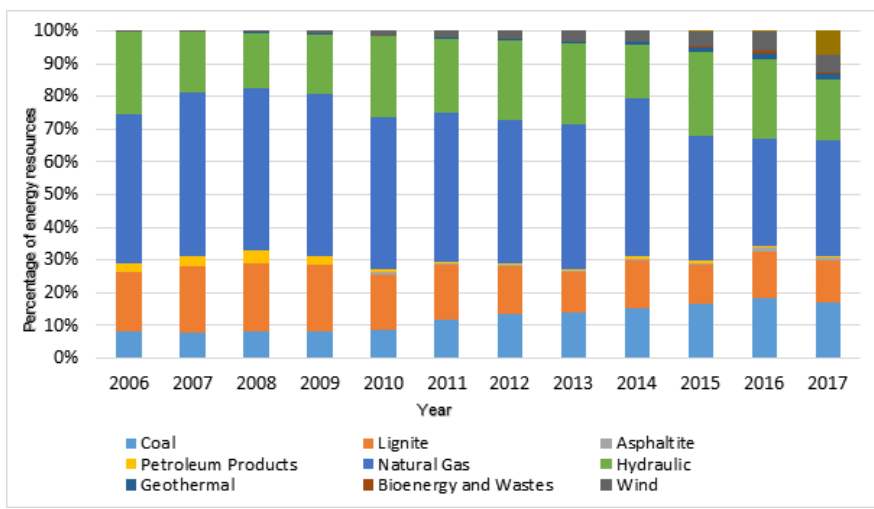

Fig.5. Electricity generation rates according to types of energy resources between 2006-2017 (\%) [29].

Table 1 presents the energy generation data of the resources used to generate electrical energy in Turkey between the years 2006 and 2017 (GWh) [30]. As shown in Table I, recently, the production rates of RESs such as wind, solar, geothermal and biomass have been increasing year by year. In particular, the rates of wind and solar energy in energy production have been significantly greater as compared with other energy resources. Electricity generation from solar energy has increased about 20 times reaching to 20,291 GWh in 2017, owing to incentives and investments, while it was $1,043 \mathrm{GWh}$ in the previous year [30]. 
BALKAN JOURNAL OF ELECTRICAL \& COMPUTER ENGINEERING， Vol. 8, No. 1, January 2020

TABLE I

THE RESOURCES USED IN THE ELECTRICAL ENERGY GENERATION BETWEEN 2006-2017 IN TURKEY (GWh)

\begin{tabular}{|c|c|c|c|c|c|c|c|c|c|c|c|}
\hline \multirow[b]{2}{*}{ Year } & \multicolumn{11}{|c|}{ Types of Energy Resources (GWh) } \\
\hline & Coal & Lignite & Asphaltite & $\begin{array}{l}\text { Petroleum } \\
\text { Products }^{1}\end{array}$ & $\begin{array}{c}\text { Natural } \\
\text { Gas }^{2}\end{array}$ & Hydraulic & Geothermal & $\begin{array}{c}\text { Bioenergy } \\
\text { and } \\
\text { Wastes }\end{array}$ & Wind & Solar & Total Energy \\
\hline 2017 & 54,387 & 40,694 & 2,395 & 1,200 & 110,490 & 58,218 & 6,127 & 2,889 & 17,904 & 20,291 & 297,278 \\
\hline 2016 & 50,829 & 38,570 & 2,874 & 1,926 & 89,227 & 67,231 & 4,819 & 2,372 & 15,517 & 1,043 & 274,408 \\
\hline 2015 & 43,751 & 31,336 & 1,079 & 2,224 & 99,219 & 67,146 & 3,425 & 1,758 & 11,653 & 194 & 261,784 \\
\hline 2014 & 38,693 & 36,615 & 954 & 2,145 & 120,576 & 40,645 & 2,364 & & 8,520 & 17 & 251,963 \\
\hline 2013 & 32,792 & 30,262 & 732 & 1,739 & 105,116 & 59,420 & 1,364 & & 7,558 & & 240,154 \\
\hline 2012 & 32,475 & 34,689 & 850 & 1,639 & 104,499 & 57,865 & 899 & & 5,861 & & 239,497 \\
\hline 2011 & 26,531 & 38,870 & 817 & 904 & 104,048 & 52,339 & 694 & & 4,724 & & 229,396 \\
\hline 2010 & 18,120 & 35,942 & 984 & 2,180 & 98,144 & 51,796 & 668 & & 2,916 & & 211,208 \\
\hline 2009 & 16,148 & 39,089 & 448 & 4,803 & 96,095 & 35,959 & 436 & & 1,495 & & 194,813 \\
\hline 2008 & 15,858 & 41,858 & & 7,519 & 98,685 & 33,270 & 162 & & 847 & & 198,418 \\
\hline 2007 & 15,136 & 38,295 & & 6,527 & 95,025 & 36,007 & & & 355 & & 191,558 \\
\hline 2006 & 14,217 & 32,433 & & 4,340 & 80,691 & 44,338 & & & 127 & & 176,300 \\
\hline
\end{tabular}

${ }^{1}$ It is the sum of Petroleum Odor, Fuel Oil, Motor, Gasoline, LPG, Refinery Gas, Aviation Fuel, Gas Oil, Naphtha, Intermediates, Base Oil, White Alcohol, Bitumen, Marine Motor, Marine Fuel and others.

$29155 \mathrm{kcal} / \mathrm{Sm} 3$ at $15^{\circ} \mathrm{C}$ and 1 atmosphere pressure.

Coal and lignite are the primary local energy resources in Turkey in addition to hydropower and the other RESs. Turkey does not have too many reserves of natural gas and/or other fossil resources. Table II shows the installed power capacity in
Turkey. In 2017, extracted coal and lignite formed about 23\% of Turkey's primary energy resources, whereas its renewable energy capacity was about $48 \%$ of the total energy in the installed capacity [30].

TABLE II

INSTALLED POWER CAPACITY BETWEEN 2006-2017 IN TURKEY

\begin{tabular}{|c|c|c|c|c|c|c|c|c|c|c|c|}
\hline \multirow[b]{2}{*}{ Year } & \multicolumn{11}{|c|}{ Types of Energy Resources (MW) } \\
\hline & Coal & Lignite & Asphaltite & $\begin{array}{l}\text { Petroleum } \\
\text { Products }^{1}\end{array}$ & $\begin{array}{c}\text { Natural } \\
\text { Gas }^{2}\end{array}$ & Hydraulic & Geothermal & $\begin{array}{c}\text { Bioenergy } \\
\text { and } \\
\text { Wastes }\end{array}$ & Wind & Solar & Total Power \\
\hline 2017 & 9,171 & 9,090 & 405 & 986 & 26,639 & 27,273 & $1,063.7$ & 634 & 6,516 & 3,421 & 85,200 \\
\hline 2016 & 7,824 & 9,270 & 405 & 645 & 25,771 & 26,681 & 821 & 496 & 5,751 & 833 & 78,497 \\
\hline 2015 & 6,690 & 8,697 & 135 & 1,105 & 24,906 & 25,868 & 624 & 370 & 4,503 & 249 & 73,147 \\
\hline 2014 & 6,398 & 8,281 & 135 & 1,181 & 25,508 & 23,643 & 405 & & 3,630 & 40 & 69,520 \\
\hline 2013 & 4,248 & 8,223 & 135 & 1,229 & 24,579 & 22,289 & 311 & & 2,760 & & 64,008 \\
\hline 2012 & 4,248 & 8,193 & 135 & 1,884 & 20,399 & 19,609 & 162 & & 2,261 & & 57,059 \\
\hline 2011 & 4,216 & 8,199 & 135 & 1,778 & 19,477 & 17,137 & 114 & & 1,729 & & 52,911 \\
\hline 2010 & 3,616 & 8,199 & 135 & 2,046 & 18,175 & 15,832 & 94 & & 1,320 & & 49,524 \\
\hline 2009 & 2,256 & 8,110 & 135 & 2,140 & 16,617 & 14,553 & 77 & & 792 & & 44,761 \\
\hline 2008 & 1,986 & 8,205 & & 2,290 & 15,055 & 13,829 & 30 & & 364 & & 41,817 \\
\hline 2007 & 1,986 & 8,211 & & 14,576 & 14,576 & 13,418 & & & 146 & & 40,836 \\
\hline 2006 & 1,986 & 8,211 & & 2397 & 14,331 & 13,086 & & & 59 & & 40,565 \\
\hline
\end{tabular}

${ }^{1}$ It is the sum of Petroleum Odor, Fuel Oil, Motor, Gasoline, LPG, Refinery Gas, Aviation Fuel, Gas Oil, Naphtha, Intermediates, Base Oil, White Alcohol, Bitumen, Marine Motor, Marine Fuel and others.

$29155 \mathrm{kcal} / \mathrm{Sm} 3$ at $15^{\circ} \mathrm{C}$ and 1 atmosphere pressure.

The Republic of Turkey Energy Market Regulatory Authority (EMRA) and related organisations classify electrical energy production according to organisations as Transfer of
Operational Right, Build Operate, Build Operate Transfer, Free Production Company, Electricity Generation Corporation (EUAS) and Auto-producers. Fig. 6 shows the distribution of 
electricity generation in 2016. Free production companies have the largest share in electric energy production with a rate of $61.48 \%$. The second organization with the largest share is EUAS, with a rate of $26 \%$ [32].

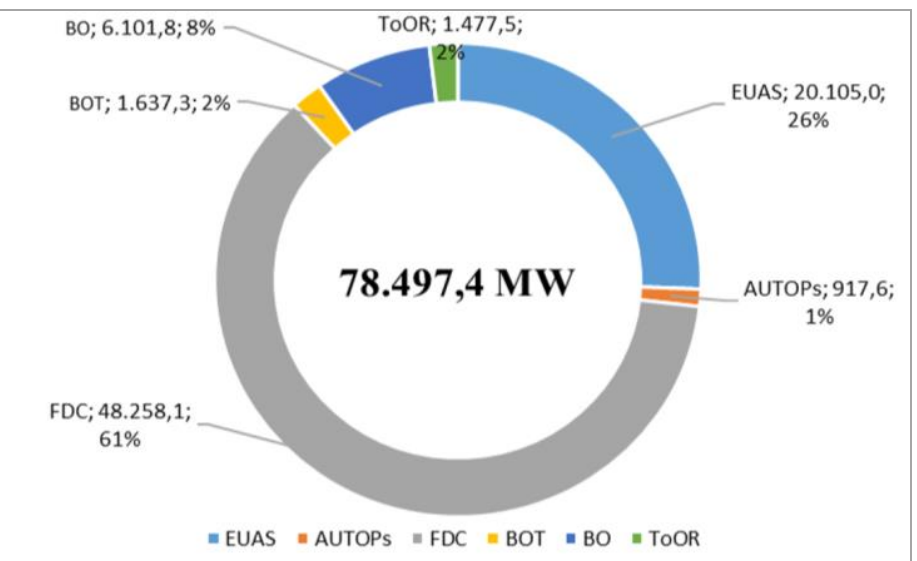

EUAS: Electricity Generation Corporation

BOT: Build Operate Transfer

AUTOPs: Autoproducers

BO: Build Operate

FDC: Free Production Company

ToOR: Transfer of Operational Right

Fig.6. Distribution of electricity generation in 2016 (\%) [30].

An examination of the private sector distribution of electrical energy production reveals that the public sector's total share (including current contracts) in the production was $60.3 \%$ in 2006 , and decreased to $25.6 \%$ in 2016 . Conversely, the private sector's total share in the production was $39.7 \%$ in 2006, and increased to 74.4\% in 2016 (See Fig. 6) [33]. As shown in Fig. 7, the public sector's share is decreasing day by day compared to past years. This decrease implies that a large part of the system's newly added electrical power plants is owned by private companies, and/or some of the existing power plants have been handed over to the private sector for operation.

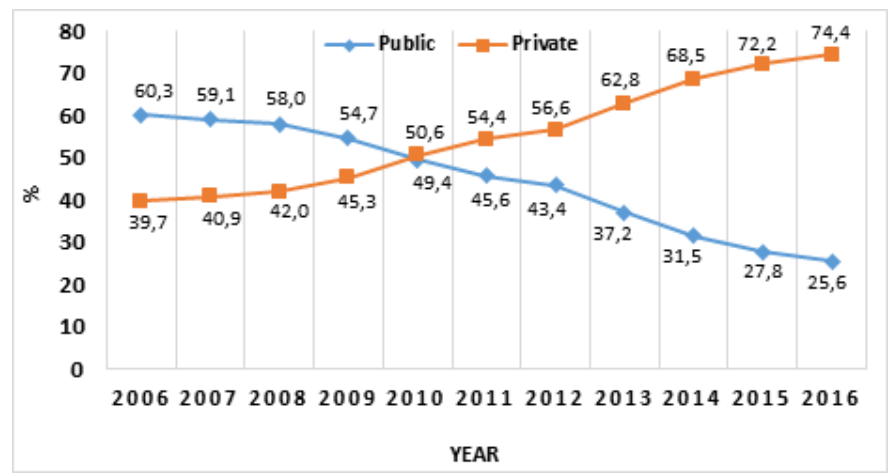

Fig.7. Public-private sectors variation of the production of the electrical energy between 2006-2016 (\%) [31].

Fig. 8 shows the rates of domestic and imported resources in Turkey's installed power for the years 2000-2016. The total share of imported resources in the production was $33.7 \%$ in 2000 and increased to $43.4 \%$ in 2016 . The share of domestic resources in 2000 was $66.3 \%$ and decreased to $56.6 \%$ in 2016 [33].

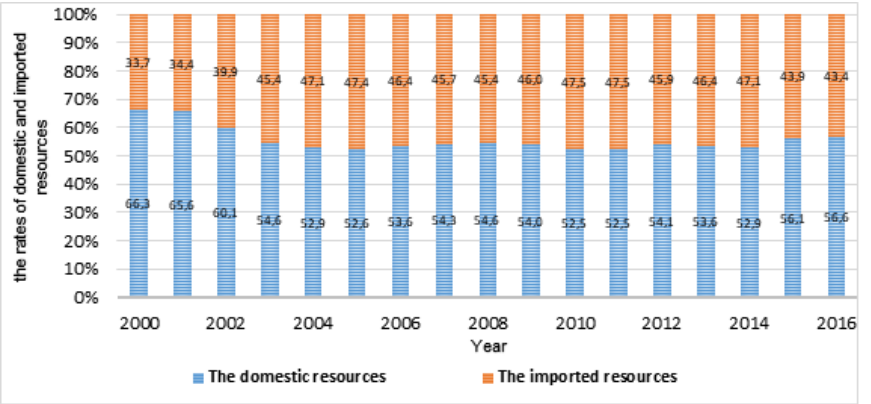

Fig. 8. The rates in the use of the domestic and the imported resources in Turkey's installed power between 2000-2016 (\%) [31].

Turkey has exhibited an average economic growth rate of $5 \%$ in the last 15 years. This growth rate causes rapid increase in energy demands. Yet, the use of natural gas plants, whose installation time and cost are low, has increased. However, in the near future, the use of imported resources is expected to decrease, owing to local investment and incentives that have been provided for the RESs exploitation in recent years.

\section{UTILIZATION OF RENEWABLE ENERGY ON TURKEY'S ENERGY PRODUCTION}

Following the global trend, significant progress is witnessed in Turkey's renewable energy utilisation. Due to its unique geographical location, Turkey has the opportunity to benefit from all renewable energy sources. Fig. 9 presents Turkey's installed power capacity with respect to a comparison between the primary source of energy and other resources, for 2017. The comparison reveals that the installed power capacity of all resources except liquid fuels has increased between 2006 and 2017. Upon examining RESs, hydraulic energy is also observed to have a greater rate of installed power capacity, followed by wind energy, solar energy and geothermal energy.

Whereas theoretical potential of hydropower resources having the most important place in Turkey's renewable energy potential is $433 \mathrm{TWh} /$ year, assessable and economic potentials are 216 and $140 \mathrm{TWh} /$ year, respectively [30]. Turkey's theoretical hydroelectric potential corresponds to $1 \%$ of the world theoretical potential. Besides, its economic hydroelectric potential also corresponds to $16 \%$ of Europe's economic hydroelectric potential [30]. In recent years, investments of electricity production from hydraulic energy source has been canalised to small-scale power plants. By the end of 2017, 628 active hydropower cumulative installed capacity of power plants in Turkey was 27,265 MW [30]. This value corresponds to approximately $32 \%$ of the total installed capacity of Turkey as seen in Table II. 


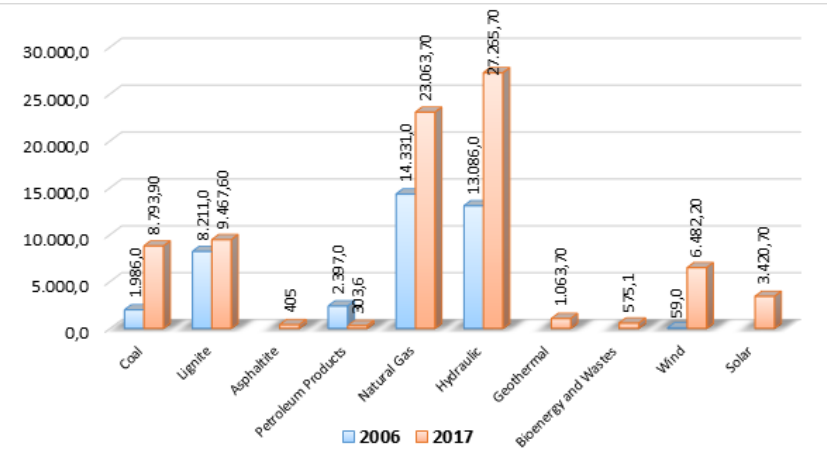

Fig.9. Turkey installed capacity according to the primary energy source for 2006 and 2017 [31].

The Turkish Parliament's regulations have come into force in order to increase the renewable energy utilisation in electricity production, since 2005 . For this reason, the installed wind capacity increased more than 100 times to $6,482 \mathrm{MW}$ by end of 2017. The Republic of Turkey Ministry of Energy and Natural Resources (MENR) has set a 2023 wind energy target of up to 20,000 MW. The production of the electrical energy from wind turbines was 15,524 GWh in 2017 [30].

Turkey has significantly increased the utilization of geothermal energy in the past few years. This increase is substantially due to the geothermal law with favouring regulations, feed-in tariffs and a target of $1 \mathrm{GW}$ of geothermal power capacity to be installed by 2023 . It is reported that 225 new geothermal fields have been discovered in year 2015. A total of 10 new power units of $159 \mathrm{MW}$ have been completed and total installed power capacity has risen to 1,063 MW [30].

In addition to other renewable energy resources, Turkey invests on bioenergy conversion technologies, as well. There are 122 Bioenergy Power Plants with 575.1 MW installed power, which correspond to $0.7 \%$ of installed power capacity of Turkey by end of 2017. Electricity production using bioenergy and wastes was $1,758 \mathrm{GWh}$, corresponding to $0.95 \%$ of total electricity production of Turkey in 2017 [30].

Significant improvements are observed in Turkey's renewable energy utilisation, especially in the past 15 years. Incentives, investments and legal regulations paved the way for this progress. Consequently, the ratio of renewable energy in the total generated energy is reached to about $1 / 2$ in 2017 . This figure was $1 / 4$ in 2006.

\section{PRESENT AND FUTURE UTILIZATION OF SOLAR ENERGY IN TURKEY}

Solar energy as an RES has greater potential in Turkey than in other European countries. However, this potential has remained largely unexploited. Nevertheless, in recent years, incentives have been granted and project calls have been opened to investors aiming to increase the use of RESs, especially solar energy. Consequently, solar energy is expected to significantly contribute to Turkey's installed power in the near future.

\section{A. Solar Energy Potential in Turkey}

Turkey has a good geographical location, and therefore high solar energy potential. Fig.10 shows the distribution of Turkey's average global horizontal irradiance between 1994 and 2015 [34]. Using the data obtained from MENR, it can be said that Turkey has an average annual total sunlight duration of 2,737 hours $(7.5 \mathrm{~h}$ per day on average), an average total radiation intensity of $1,527 \mathrm{kWh} / \mathrm{m}^{2}$-year (daily total of 4.2 $\mathrm{kWh} / \mathrm{m}^{2}$-day). In terms of months, maximum solar energy can be produced in June and July, and minimum solar energy can be produced in December and January [35]. The region with the highest solar radiation in Turkey is the Southeastern Anatolia Region, as seen in Fig. 11, followed by the Mediterranean Region. The region with the lowest potential for solar radiation is the Black Sea region with a total radiation intensity of about $1200 \mathrm{kWh} / \mathrm{m}^{2}$-year [35]. However, the total radiation intensity in this region is quite higher than that in most European countries.

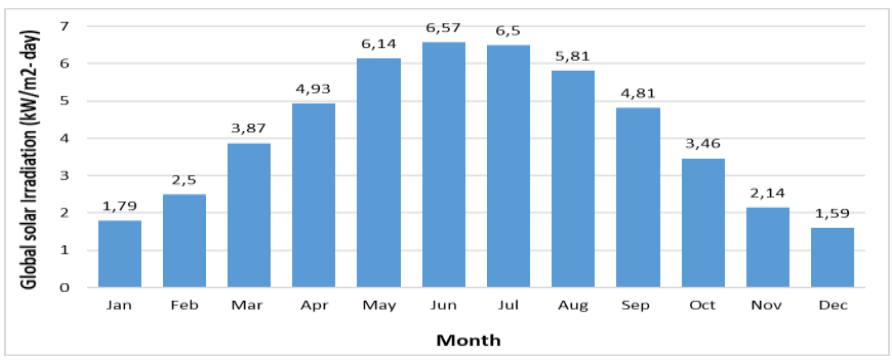

Fig. 10. Average global solar irradiation per $\mathrm{m}^{2}$-day in Turkey.

Solar power plant technologies can be divided into two main groups, widely varying in terms of method, material and technological level:

- Thermal Solar Technologies and Concentrating Solar Power: Heat derived from solar energy can be used directly or indirectly for electricity generation in these systems.

- Photovoltaic Systems: These systems are based on semiconductor-based devices that directly convert solar radiation to electricity.

Turkey takes an important place in the world in the use of solar thermal capacity. In 2017, an estimated $35 \mathrm{GW}$ of new solar thermal energy plant was commissioned in the world. China is the leading country in the new installation, followed by Turkey, India, Brazil and the United States [23]. The total installed solar collector area in Turkey is estimated to be approximately $20 \mathrm{~km}^{2}$. About $50 \%$ of the produced planar collectors and all vacuum tube collectors are used in the country. Approximately 823,000 TEP of heat energy was produced using solar collectors in 2017. Residential use of the produced heat energy was 536,000 TEP and industrial use was 287,000 TEP [35]. 


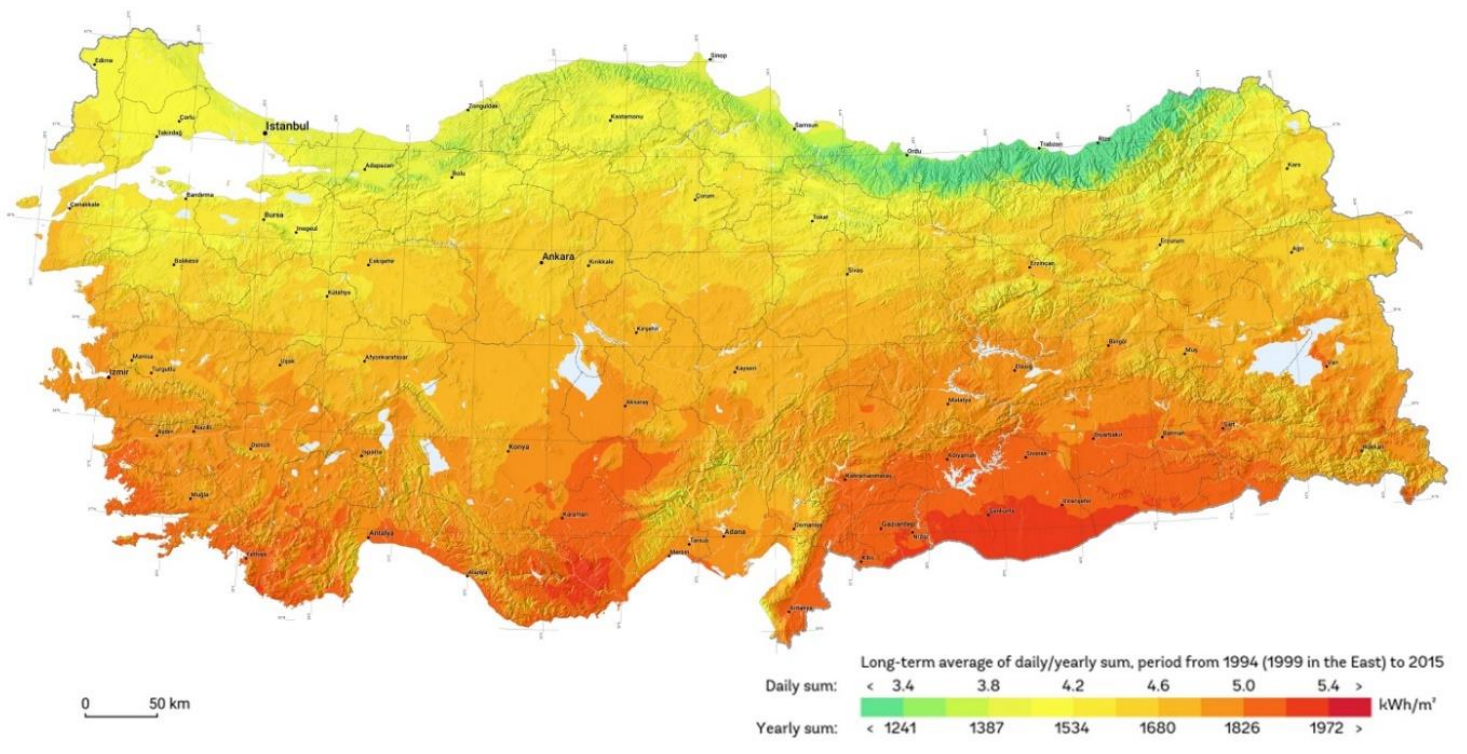

\section{SOLAR RESOURCE MAP GLOBAL
HORIZONTAL
IRRADIATION
TURKEY}

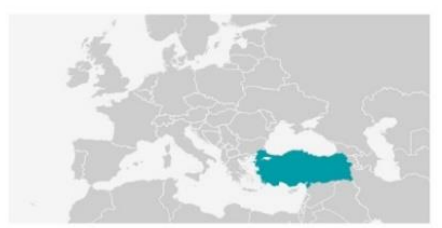

\begin{abstract}
DESCRIPTION
This solar resource map provides a summary of the estimated solar energy available for power generation and other energy applications. It represents the average daily/yearly sum of global horizontal irradiation (GHI), covering a period from 1994 to 2015 in the west and from 1999 to 2015 in the east of the country. The underlying solar resource database is calculated by the Solargis model from atmospheric and satellite data with 15-minute and 30-minute time step. The effects of terrain are considered at nominal spatial resolution of $250 \mathrm{~m}$.

There is some uncertainty in the yearly $\mathrm{GHI}$ estimate as a result of limited potential for regional model validation due to a lack of high quality ground measurement data, which is estimated to vary regionally from approx. $5 \%$ to $7 \%$. $\mathrm{GHI}$ is the most important parameter for energy yield calculation and performance assessment of flat-plate photovoltaic (PV) technologies.
\end{abstract}

Fig.11. Turkey's global solar atlas source: World Bank Group [32].

\section{B. Present Policy and Legal Aspects of the Feed-in-Tariff of Photovoltaic Systems in Turkey}

In recent years, awareness has grown parallel to technological developments leading to incentives and investments in photovoltaic systems in Turkey. Therefore, many domestic and foreign companies in the energy sector are interested in policies on investment issues concerning solar power plants in Turkey.

In recent years, the investment capacity for solar power systems is increasing on a daily basis with announced incentive prices and 10-year purchase guarantee. To support entrepreneurs who wish to invest in this sector in Turkey, Renewable Energy Law No. 5346, Electricity Market Law No. 6446 and Unlicensed Electricity Production Regulation have been modified. With current arrangements, the value of $1 \mathrm{kWh}$ of electricity produced by solar power plants operating until 31 December, 2020 for all real and legal persons will be 13.3 cent $/ \mathrm{kWh}$. However, this price increases up to $20 \mathrm{cent} / \mathrm{kWh}$ depending on the domestic devices used in the construction of the power plant. If all devices are domestic, the price is 20 cent $/ \mathrm{kWh}$. Solar power plant license applications for $600 \mathrm{MW}$ capacity were received by EMRA in 38 cities covering 27 regions between 10 and 14 June, 2013. Furthermore, 496 solar power plant license applications were received for 7,930 MW capacity. Those eligible for investments are entitled to a license in these applications. Fig. 12 shows the participation trend in the competition for electricity generation from solar energy.

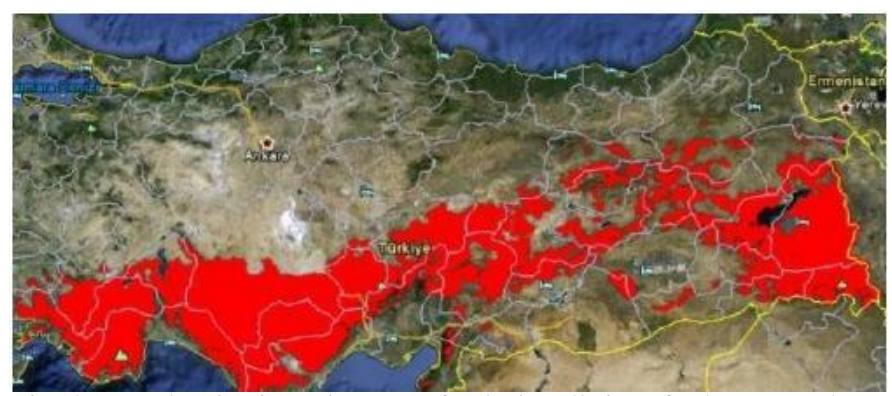

Fig.10. Map showing incentive zones for the installation of solar power plants covering 27 districts 38 cities for 600MW capacity received from EMRA [30].

Up to $1 \mathrm{MW}$ of electricity can be produced without a license for solar power plants within the scope of the Regulation on Unlicensed Electricity Generation in Electricity Market, dated 2 October, 2013 and numbered 28783. Moreover, investors are encouraged by the government for roof and solar power plant system applications. The capacity entering the operation, which was $359.04 \mathrm{MWe}$ at the end of 2015 , in the production of unlicensed electricity has increased about three times to 1,048.21 MWe as of the end of 2016 . 
Herein, the largest share belongs to solar power plants with $89.60 \%$, followed by natural gas at $4.95 \%$ and biomass at $3.47 \%$ [32].

\section{Capacity of Photovoltaic Systems for Energy Production in Turkey}

In terms of solar energy production, Turkey has a better position as compared with many developed and developing countries owing to its geographical location (a sunny belt between $36^{\circ} \mathrm{N}$ and $42^{\circ} \mathrm{N}$ ). In an age when energy demands are increasing parallel to the development of new technology, the use of renewable energy-based systems instead of traditional ones is expected to diminish the country's dependence on foreign energy sources. For this reason, incentives and project calls, supported by the corresponding legal arrangements, in the field of solar power plant applications have encouraged many domestic and foreign investors to invest in this field in Turkey.

Turkey's cumulative installed capacity of solar power plants (40 MW), including licensed and unlicensed plants, formed $0.06 \%$ of the total installed power plant capacity in 2014, according to the data provided by the MENR. As of the end of 2017, Turkey's cumulative installed power capacity (3421 MW) increased to $4.01 \%$ of the total installed power capacity with completed licensed and unlicensed plants supported via incentives and projects calls in the field of solar power plant applications. The installed power capacity in 2017 increased by about 85 times compared to the year 2014 .

The production-capacity-projection-model study of MENR predicted the total installed power by type of energy source, in accordance with macroeconomic targets, between 2016 and 2020 (Turkish Electricity Transmission Company). The capacity of solar power plants (in power plants, public facilities under construction, LicensedAssociate/Licensed/Unlicensed/Solar Production Facilities within the scope of the (Renewable Energy Resource Area) RERA Project) for the year 2016, was estimated at 605.3 MW according to this report [36]. The installed capacity at the end of 2016 was $833 \mathrm{MW}$. Therefore, the existing installed power was estimated to be $37.62 \%$ higher than expected. The installed capacity for 2020 was determined to be $4,084.7 \mathrm{MW}$ [36]. This capacity already has increased about 4 times to $3,421 \mathrm{MW}$ in 2017, owing to incentives and investments when compared to the previous year. Solar power plant capacity is expected to reach well above the projected value in 2020 .

1,500 MW solar photovoltaic power plants are expected to be installed over an area of $27.2 \mathrm{~km}^{2}$ declared as the RERA in the Karapinar district of the Konya province (Central Anatolia Region). Installation will be performed in two stages, providing 1,000 MW and $500 \mathrm{MW}$ of energy (Karapinar Energy Specialised Industrial Zone Part 1), as shown in Fig. 13.

The construction of an 1,800 MW solar photovoltaic power plant is planned for the tender's second part concerning the $32.4 \mathrm{~km} 2$ area declared as Karapinar RERA (Karapinar Energy Specialised Industrial Zone Part 2). Part 1 of the tender by the Energy and Natural Resources Ministry was realised through the participation of four consortiums in 2017. The Kalyoncu-Hanwha Group submitted the lowest bid of 6.99 cent $/ \mathrm{kWh}$ in the tender, which was completed in 18 rounds.
Under this bid, a factory installation with a minimum production capacity of $500 \mathrm{MW}$ PV modules per year will be implemented in Turkey.

In the Official Gazette dated Sep. 29, 2018 and numbered 30550, new RERA areas were identified. These areas, Niğde/Bor, Şanlıurfa/Viransehir and covering the boundaries of three district Hatay/Erzin Adana/Toprakkale and Osmaniye/Ceyhan are the three RERA areas.

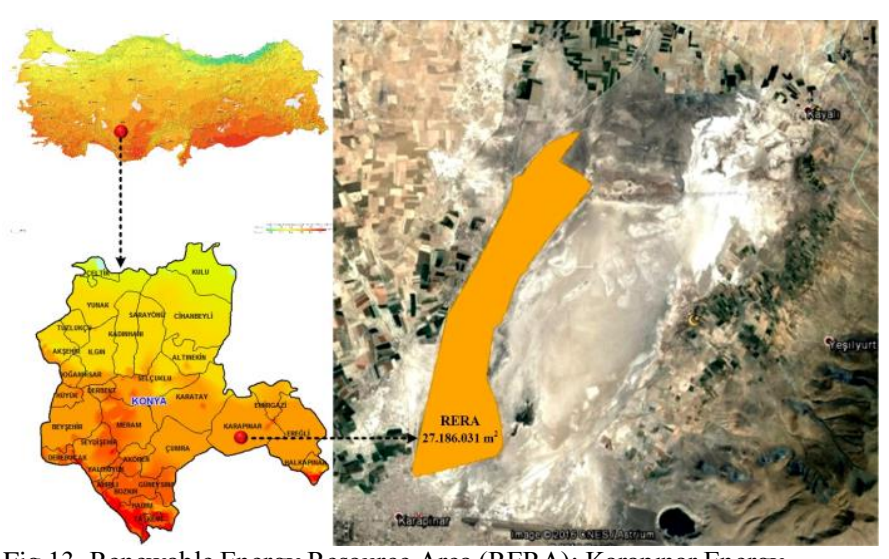

Fig.13. Renewable Energy Resource Area (RERA): Karapinar Energy Specialized Industrial Zone Part 1, 27.186.031 $\mathrm{m}^{2}$, Konya, Turkey [33].

In this study, more than 700 solar photovoltaic power plants in Turkey are identified and mapped. For the mapping, the power plants are divided into four categories: active, in the construction phase, in the office phase and planned power plants. By the end of 2017, active solar photovoltaic cumulative installed capacity of power plants in Turkey was 3,421 MW, exhibiting an increase of 4.11 times over the previous year. Solar power installed capacity at the regional scale is mostly focused in the south of the Central Anatolian region, followed by the Mediterranean and Aegean regions as seen in Fig. 14. When evaluated on a provincial basis, installed power capacity is observed to be the highest in Konya, followed by Kayseri and Ankara.

Although solar radiation is the most intense in the Southeastern Anatolia Region, there are more solar photovoltaic power plants in Central Anatolia and in the Mediterranean Region. The criteria for solar power plant installation depend on land choice (no-ghost effect, southfacing and flat areas with less than $8 \%$ slope, geological and hydrological factors, not in agricultural fields, etc.), environmental climatic conditions (temperature, humidity, wind, snow, etc.), geopolitical risk factors (such as terrorism) and proximity to transformer centers. Thus, land structure and geopolitical risk factors play important roles in the less-thanexpected solar photovoltaic power plant capacity of the Southeastern Anatolia Region. Furthermore, more solar photovoltaic power plants exist in the construction stage in the Central Anatolia, Mediterranean and Aegean regions. 


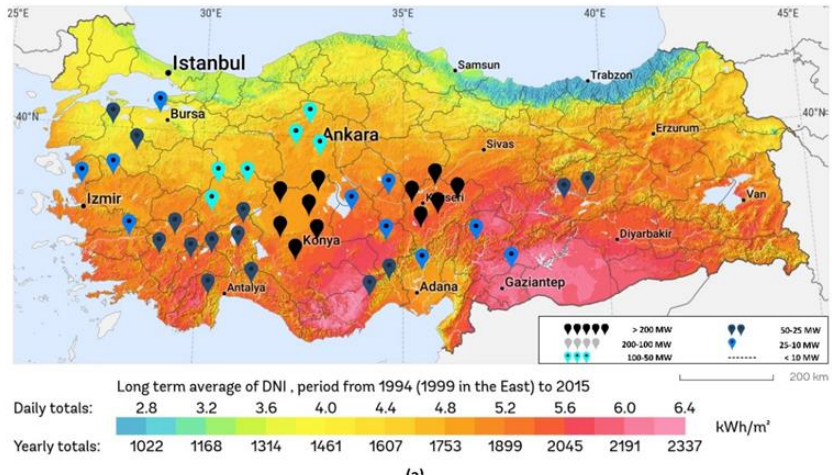

(a)
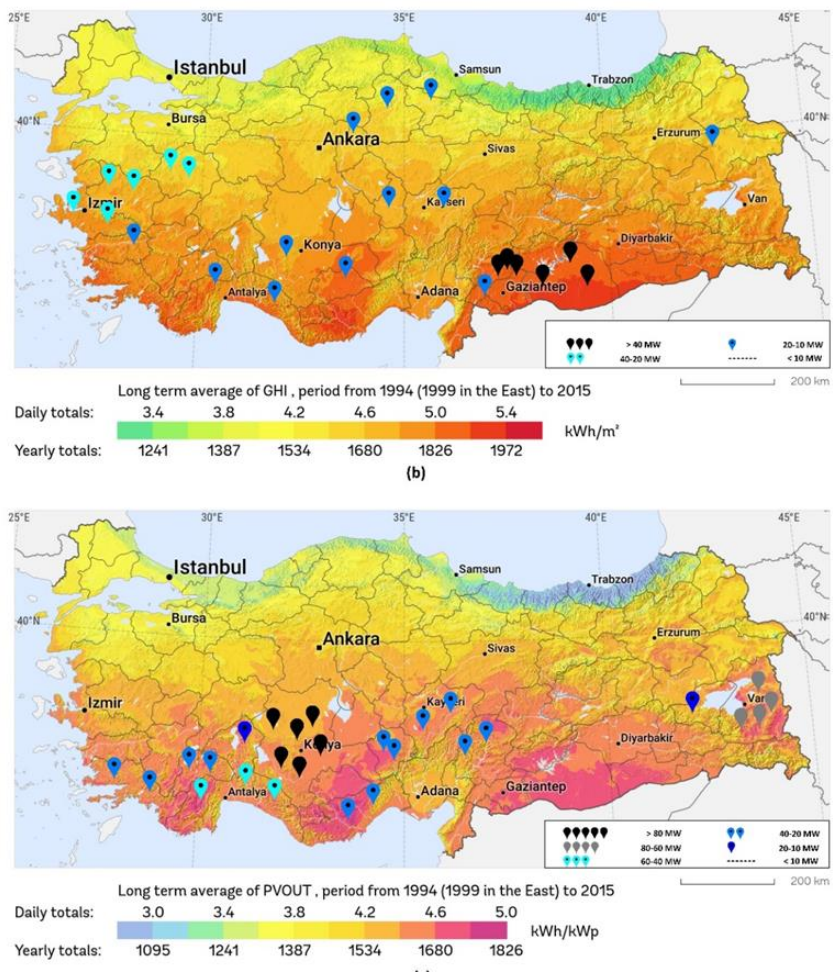

Fig.14. Map showing of Solar Photovoltaic Power Plant Capacity (MW) as active (a), construction phase (b), office phase (c).

\section{V.CONCLUSION}

Rapid population growth and industrialisation in Turkey have resulted in a rapidly increasing energy demand. This energy demand reflects the increased potential for economic and socio-cultural development. Different types of energy resources are used to meet the energy demand of Turkey. In this regard, the most effective and reliable sources of energy are RESs that do not produce harmful carbon emissions. Due to the incentives provided and the investments made in the last few years, the share of renewable energy in the total production of energy increased from $1 / 4$ in 2006 to about $1 / 2$ in 2017. Thus, the capacity utilisation rate of RESs has increased extremely rapidly. By the end of 2017, the installed power capacity of solar photovoltaic power plants increased by 4.11 times compared to the previous year, reaching 3,421 MW. This value corresponds to $4 \%$ of the total installed power. The installed capacity for 2020 was determined to be 4,084.7 MW. Because this capacity already has increased to
3,421 MW in 2017, solar power plant capacity is expected to reach well above the projected value in 2020 owing to incentives and investments. At a regional scale, solar power installed capacity is mostly located in the south of the Central Anatolian region, followed by the Mediterranean and Aegean regions. When evaluated on a provincial basis, the installed capacity is mostly focused in Konya, followed by Kayseri and Ankara. Although the Southeastern Anatolia Region has the highest solar radiation levels in Turkey, solar photovoltaic power plants density is highest in Central Anatolia and the Mediterranean region. The terrain selection criteria for solar power plants include land structure, climate, geopolitical risk factors and proximity to substation centres. Consequently, land structure and especially geopolitical risk factors play a crucial role in the observed lack of solar photovoltaic power plants capacity in Southeastern Anatolia. As a result, supported by the required legal arrangements made by the concerned public and other related institutions, and owing to project calls and incentives for solar power plants, many domestic and foreign investors have been encouraged to work in Turkey. In this context, solar energy power capacity is expected to significantly contribute to the total installed power capacity over the next few years.

\section{REFERENCES}

[1] Pérez-Lombard L, Ortiz J, Pout C. A review on buildings energy consumption information, Energy and Buildings, 2008, 40(3):394-398.

[2] Kalogirou SA. Solar energy engineering: process and systems, vol. 1st, California: Academic Press, 2009.

[3] Tukenmez M., Demireli E. Renewable energy policy in Turkey with the new legal regulations, Renewable Energy, 2012,39:1-9.

[4] Guo S, Liu Q, Sun J, Jin H. A review on the utilization of hybrid renewable energy, Renewable and Sustainable Energy Reviews, 2018, 91:1121-1147.

[5] Esen, V, Neşe, S, Sağlam, Ş, Oral, B, "The Training of Renewable Energy Systems Undergraduate Studies". Balkan Journal of Electrical and Computer Engineering 5 (2016): 26-29.

[6] Sahin, F. E., Musa Yilmaz. "High concentration photovoltaics (HCPV) with diffractive secondary optical elements." Photonics. Vol. 6. No. 2. Multidisciplinary Digital Publishing Institute, 2019.

[7] Montoya FG, Aguilera MJ, Manzano-Agugliaro F. Renewable energy production in Spain: A review, Renewable and Sustainable Energy Reviews, 2014, 33:509-531.

[8] Yilmaz, M, "Real Measure of a Transmission Line Data with Load Forecast Model for The Future". Balkan Journal of Electrical and Computer Engineering 6 (2018): 141-145

[9] Tur, M, "The Impact of Emerging Renewable Energy on Capacity Mechanisms in Power Systems and Expert Opinion". Balkan Journal of Electrical and Computer Engineering 7 (2019): 319-325

[10] Salam M, Yazdani M, Rahman Q, Nurul D, Mei SF, Hasan S. Investigation of wind energy potentials in Brunei Darussalam, Front. Energy, 2018, 125:1-11.

[11] Dirks L, Dirks G, Wu J. Evolving perspectives on biofuels in the United States, Front. Energy, 2012, 6:379-393.

[12] Yuksel I. Energy production and sustainable energy policies in Turkey, Renewable Energy, 2010, 35: 1469-1476.

[13] World Bank, "World Bank, World Development Indicators (WDI)," Our World in Data, 2014. https://ourworldindata.org/grapher/globalelectricity-production-by-source,2018-1-24.

[14] Goetzberger A, Hoffmann V. Photovoltaic Solar Energy Generation, Germany: Springer-Verlag Berlin Heidelberg, 2005.

[15] UNFCCC, "Climate change: Climate change: Impacts, vulnerabilities and adaptation in developing countries" United Nations Framework Convention on Climate Change, Bonn, Germany, 2007. 
[16] Owusu P A, Asumadu-Sarkodie S. A review of renewable energy sources, sustainability issues and climate change mitigation, Cogent Engineering, 2016, 3(1167990):1-14.

[17] Goel A, Bhatt R. Causes and Consequences of Global Warming, Int J LifeSc Bt \& Pharm Res, 2012, 1(1):27-31.

[18] IEA, "CO2 Emissions from Fuel Combustion, IEA, 2017," INTERNATIONAL ENERGY AGENCY, 2017. https://www.iea.org/publications/freepublications/publication/co2emissions-from-fuel-combustion----2017-edition---overview.html, 2017$1-24$.

[19] Energy Information Administration (EIA), "In: International Energy Outlook 2009 (IEO2009)," Official energy statistics from the U.S., 2009.

[20] Turkish Statistical Institute (TUIK), "Energy statistics. Electricity production and distribution." Republic of Turkey: Prime Ministry, Ankara, 2016.

[21] Nguyen K Q. Alternatives to grid extension for rural electrification: Decentralized renewable energy technologies in Vietnam, Energy Policy, 2007,35(4):2579-2589.

[22] Mekhilef S, Saidur R, Safari A. A review on solar energy use in industries, Renew Sustain Energy Rev, 2011,15(4):1777-1790.

[23] RENEWABLES 2018 GLOBAL STATUS REPORT, Renewable Energy Policy Network for the 21st Century, 2018.

[24] Hosenuzzaman M, Rahim N, Selvaraj J, Hasanuzzaman M, Malek A, Nahar A. Global prospects, progress, policies, and environmental impact of solar photovoltaic power generation, Renewable and Sustainable Energy Reviews, 2015, 41:284-297.

[25] Solangi K, Islam M, Saidur R, Rahim N, Fayaz H. A review on global solar energy policy, Ren Sustain Energy Rev, 2011,15(4):2149-2163.

[26] Ahmed F, Al Amin A, Hasanuzzaman M, Saidur R. Alternative energy resources in Bangladesh and future prospect. Renew Sustain Energy Rev, 2013, 25:698-707.

[27] Lynn PA. Electricity from sunlight: an introduction to photovoltaics. West Sussex: John Wiley \& Sons Ltd, 2010.

[28] Kaya D. Renewable energy policies in Turkey, Renewable and Sustainable Energy Reviews, 2006,10: 152-163.

[29] Koç E, Şenel M C. Dünyada ve Türkiye'de Enerji Durumu -The State of Energy in World and Turkey - General Evaluation, Mühendis ve Makina, 2013:54(639):32-44.

[30] Ministry of Energy and Natural Resources (MENR), "Electricity generation-distribution statistics according to types of energy resources," Dec. 2017. http://www.eigm.gov.tr/tr-TR/Denge-Tablolari/DengeTablolari. 2018-2-26.

[31] WORLD ENERGY COUNCIL, "World Energy Resources | 2016," Copyright (C) 2016 World Energy Council., London EC3V 3NH, United Kingdom, 2016.

[32] Energy Market Regulatory Authority (EMRA), "Sector reports," http://www.epdk.org.tr/TR/Dokumanlar/Elektrik/YayinlarRaporlar/Elekt rikPiyasasiGelisimRaporu, 2016, 2018-2-26.

[33] Turkish Electricity Transmission Company (TEIAS), "Turkey's Electricity Generation-Transmission Statistics," Dec. 2016. https://www.teias.gov.tr/tr/turkiye-elektrik-uretim-iletim-istatistikleri. 2018-02-27.

[34] World Bank Group, "Global Solar Atlas, Turkey," The World Bank and International Finance Corporation (IFC), $30 \quad 012017$. http://globalsolaratlas.info/downloads/turkey.2018-02-06.

[35] Ministry of Energy and Natural Resources (MENR), "Solar energy capacity in Turkey," Dec. 2016. http://www.enerji.gov.tr/trTR/Sayfalar/Gunes. 2018-02-27.

[36] Turkish Electricity Transmission Company (TEIAS), "Turkey's electricity generation capacity for 5-year projection (2016-2020)," Ankara, 2015.

\section{BIOGRAPHIES}

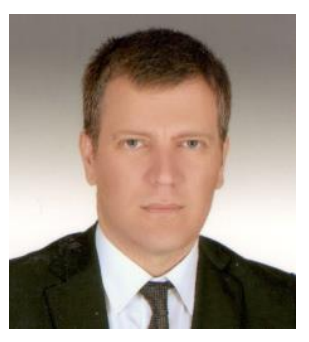

FARUK ERKEN- He received the BS degree from the Department of Electrical and Electronics Engineering, Firat University, the MSc degree from Institute of Science and Technology, Dicle University, the $\mathrm{PhD}$ degree from Institute of Science and Technology, Firat University respectively, from Turkey. He is currently an Assistant Professor in the Electrical and Electronics Engineering Department of Kastamonu University His research interests include electrical machines and control, power converters and renewable energy. 